\title{
Foreign Settlements and Modernization: The Cases of Nagasaki and Hakodate
}

\author{
Hideo Watanabe, Ph. D \\ Department of Languages and Cultures \\ William Paterson University \\ Wayne, New Jersey \\ USA
}

\begin{abstract}
Meiji Japan was much more diversified than commonly thought and their local areas reflected their distinctive developments. To explore foreign settlements of the five areas designated by the Ansei Five-Power treaties in 1858 is a good approach to exposing the diversity of Japan in the Meiji period. Yokohama and Kobe did not fully explain everything about Meiji Japan. Nagasaki and Hakodate give us different pictures of the country's past. Both Nagasaki and Hakodate were far from Edo but they were bigger and thriving more than Yokohama and Kobe. The Nagasaki foreign settlement was quite large and a multinational community, having early contact with China, Portugal, and the Netherlands. On the other hand, the Hakodate foreign settlement was small and had contact mainly with Russia. In the postwar, both Nagasaki and Hakodate experienced a drastic loss of population and have since become middle-class cities in their local regions.
\end{abstract}

Keywords: Nagasaki, Hakodate, foreign settlements, modernization, Japan, Meiji,

\section{Introduction}

The five ports designated to have foreign settlements by the Ansei Five-Power treaties in 1858 were Hakodate, Kanagawa (Yokohama), Nagasaki, Niigata, and Hyogo (Kobe). These foreign settlements were diversified in size, population, and the relations between foreigners and Japanese. Due to such distinct local characteristics, it is dangerous to generalize about the Japanese foreign settlements without looking at each of them closely.

The motto of the Meiji government was "Enrich the country, strengthen the military." It was not only government policy but also foreign settlements that greatly contributed to the modernization of Japan. I drew this conclusion, based on Yokohama and Kobe, in my paper "Foreign Settlements and Modernization: The Cases of Yokohama and Kobe" (Watanabe, 2018). Yokohama and Kobe functioned more fully as ports than the others. These two ports alone occupied 90\% of the total exports and imports of the nation in 1897. Also, these ports were in the central parts of Japan. Kanagawa (Yokohama) was located next to Edo and Hyogo (Kobe) was situated next to Osaka and Kyoto. I assumed that these two ports represented all other Japanese foreign settlements. Was my assumption right?

After Yokohama and Kobe, I took up Nagasaki, Hakodate, and Niigata and realized that it was not always correct that Yokohama and Kobe explained other foreign settlements of the Meiji Japan. On the contrary, Nagasaki and Hakodate proved to be so different from Yokohama and Kobe that it is hard to find "typical foreign settlements of Japan." Niigata was an extreme -- the Niigata port turned out to have no foreign settlement and not many foreigners living there. Since Niigata was an exception, I decided to put my focus on Nagasaki and Hakodate in this paper.

Nagasaki and Hakodate have something in common. Since they were both remote from Edo (the capital of Japan), the local areas respectively attained a unique development. Another commonality is that Nagasaki and Hakodate had much earlier contacts with foreign countries than Yokohama and Kobe. Nagasaki had long-term relations with China and Hakodate had close contact with Russia in the $19^{\text {th }}$ century.Considering these commonalities, is it possible to classify Nagasaki and Hakodate together as one, and Yokohama and Kobe as another? No. In fact, Nagasaki and Hakodate have distinctive features from each other and it is also dangerous to discuss Meiji Japan without referring to their prominent differences.

Thus, this paper is structured in the following way: Introduction; Chapter I, Nagasaki; Chapter II, Hakodate; Chapter III, Summary and Chapter IV, Comparative Study of Nagasaki and Hakodate.

\section{Nagasaki 長崎}

\section{I-1 General}

Nagasaki is located in the north-west of Kyushu island and has a long, crooked seacoast and countless gulfs, which made transportation much easier many years ago. Being influenced by the the warm current of Tsushima, Nagasaki had a mild climate and people easily inhabited the land. 
Nagasaki was geographically near China and Korea and had a close connection with China. Being near Shanghai, a great international city, Nagasaki was the first which had grown into an international port. Recently in 1979 the air route between Nagasaki and Shanghai began, too.

Nagasaki was visited by Christian missionaries early in the Middle Ages. In 1549 Francisco Xavier, a Spanish missionary, first came to Kagoshima, the most southern part of Kyushu, and then moved to Nagasaki to spread Christianity widely. Omura Sumitada 大村純忠, a lord of Nagasaki, was baptized and as a newly baptized Christian, he was requested to open a Nagasaki port to foreign countries in 1570. Nagasaki became a window of Japan open to overseas; however, as the shogunate government came to know people's equality under God in Christianity, they came to fear the increasing power of Christians. Eventually, they decided to stop foreign countries coming to Japan and this policy was called Sakoku 鎖国, the seclusion policy. Because Japan wanted to have trade with a foreign country without Christian influence, the Shogunate government constructed Dejima 出島, a small fan-shaped artificial island in the bay of Nagasaki, through which only Portuguese could enter the Nagasaki port. In 1609 a Holland ship came to Nagasaki and the shogunate government allowed the Dutch to enter Dejima and eventually the Dutch replaced the Portuguese merchants.

The $19^{\text {th }}$ century was the Age of Discovery; not only Europe but also Russia and America began approaching Japan. In 1804 the Russian mission of N. P. Rezanov came to Nagasaki to demand trade with Japan but the Shogunate government refused their request due to the seclusion policy.

Although Christianity was banned in Japan, some other cultures from Europe were brought in through Dejima. They were kasutera (a sponge cake) and tempura, for example. Foreign scholars also came to Nagasaki and educated Japanese people. In 1823 Philipp Franz Balthasar von Siebold (1796-1866) acted as a factory doctor inside Dejima. He brought up scholars of the Dutch language such as Takano Chohei 高野長平. In this manner Nagasaki made a step towards the modernization of Japan.

\section{I-2. The Site of the Nagasaki Foreign Settlement 長崎居留地}

In order to provide foreigners with housing and business opportunities, the Nagasaki magistrate undertook the foreign settlement. The foreign settlement was designed by Harry Smith Parks (1828-1885), a British diplomat. In 1850 the first construction took place in Higashi Yamate 東山手 and Minami Yamate 南山手. Then further construction was undertaken in three parts. The first part was the reclamation of the Oura 大浦 district, being completed in 1860. The second part was the Sagarimatsu 下り松 district, completed in 1861. The third part of the foreign settlement was the Umegasaki 梅香埼 district, being completed in 1864. When the Dejima 出島 area was counted as a part of the foreign settlement, the total of the six areas was 102,350 tsubo $\left(338,353 \mathrm{~m}^{2}\right.$.)In addition, there were the Shinchi 新地 and Hirobaba 広馬 districts, 6,900 tsubo $\left(22,809 \mathrm{~m}^{2}\right)$, where the Chinese lived.

In 1899 the Anglo-Japanese Treaty of Commerce and Navigation 日英通商航海条約 was concluded between Britain and Japan, in which the Japanese government decided to abolish the foreign settlements, which became mixed areas 雑居地 zakkyochi. Like other foreign settlements, the foreign settlements of Nagasaki were removed, and foreigners could live in residential zones, where Japanese originally lived.

\section{I-3. The Population of the Nagasaki Foreign Settlement}

The total population of the Nagasaki foreign settlement was 862 in 1876 . The population breakdown by country was China (616 persons, 71.5\%), Britain (131 persons, 15.2\%), America (39 persons, 4.5\%), France (21 persons, 2.4\%), Germany (15 persons, 1.7\%), etc. (Hori, 2008, 20).

\section{I-4. The Characteristics of Nagasaki}

\section{A. Relations with Foreign Countries}

The Nagasaki port was opened in the $16^{\text {th }}$ century as an area for trade with the Portuguese and Chinese. Since then the Chinese had established good relations with the Japanese after continuing to live in Japan for many generations. When I interviewed one of local Japanese informants about Chinese people living in Nagasaki, he answered that generally Nagasaki people had a good impression of Chinese residents in Nagasaki. Things were quite different in the Yokohama foreign settlement, where the Chinese were not welcomed by the local Japanese people. In fact, reflecting on the history of Yokohama, some foreigners were assassinated by the Japanese evidenced by the Namamugi Incident in 1862. (Watanabe, 2018, 4)

The China town in Nagasaki has been called Nagasaki Shinchi 新地. With concentration in that area, Chinese have lived from generation to generation, giving a great cultural influence on Nagasaki. 
There are lots of unique dishes mixed with Chinese dishes, such as Shojin Ryori 精進料理, Shippoku Ryori 卓䘞料理, Sara Udon皿うどん, and Chanpon チャンポン. Nagasaki Kunchi 長崎くんち is a famous festival in Nagasaki. It began in the late $16^{\text {th }}$ century and became a shrine festival, when the Suwa Shrine was founded in 1642. Ryumai 龍舞, the Dragon Dance is a famous performance at the festival. It was originally performed on New Year's Eve by the Chinese residents of Nagasaki.

\section{B. The TojinYashiki 唐人屋敷}

In medieval times, Chinese came to Japan together with the Portuguese and Dutch, often to assist them. The Edo government was afraid that the Chinese would spread Christianity. In 1689 the Nagasaki magistrate created the Tojin Yashiki 唐人屋敷 to keep the Chinese contained, which functioned as a Chinese version of Dejima, but its size was 9,400 tsubo $\left(31,074 \mathrm{~m}^{2}\right)$, four times as large as Dejima. The Tojin Yashiki was not so strictly guarded as Dejima and the Chinese were able to move in and out more freely; however, they had lost their freedom by 1859 when the national isolation policy ended.

In addition to the Tojin Yashiki there were other Chinese constructions in Nagasaki. One of them is the Koshi-byo 孔子 廟, a Confucian temple. Being first built in 1893 by Chinese residents of Nagasaki, it served as a place of worship and learning for the Chinese residents in Nagasaki. There were some other temples in Nagasaki, which looked like Chinese temples, such as Kofukuji 興福寺, Fukuzaiji 福済寺, and Sofukuji 崇福寺. These temples were built in a Chinese style, karayo 唐様, for Christianity was banned and the temples did not want to be mistaken for Christian churches.

\section{Dejima 出島}

Dejima was established by the Edo government in 1639 and covered an area of 120m x 75m, 3,969 tsubo $\left(13,120 \mathrm{~m}^{2}\right)$. It was like foreign settlements in the sense that foreigners were confined inside and were allowed to trade with Japan inside of the island. First Portuguese were confined (from 1636 to 1639) and then Dutch (from 1641 to 1859). However, Dejima was different from foreign settlements in origin. It was created to prevent Christianity from spreading throughout Japan, while foreign settlements were a product of the Treaty of Amity and Commerce between Japan and the US 日米修好通商条約 in 1858. Dejima became a part of the foreign settlements and lasted until 1859, when all foreign settlements over Japan were closed.

Dejima was an international market, where Westerners and Japanese exchanged their knowledge and skills. For example, Engelbart Kaempfer (1651-1716), a German doctor, came to Japan in 1690 and studied and wrote about Japan in the fields of history, society, politics, religion. Philipp Franz Balthasar von Siebold (1796-1866) achieved prominence by his studies of Japanese flora and fauna and the introduction of Western medicine to Japan. Japanese scholars came to Nagasaki and absorbed knowledge from the Europeans.

\section{Churches and Schools}

In the foreign settlement time, since Christianity was banned, foreigners wanted to build churches to conduct religious services. The first Catholic church that appeared in the Nagasaki foreign settlement was Oura Cathedral 大浦天主堂 at Minamiyamate, South Hill and it was completed in 1865. The number of Christian churches in Nagasaki is 971 at present and is the highest all over Japan. In comparison, Yokohama has 93 churches, and most of the residents in Nagasaki are Catholics.

Schools contributed to the enrichment of the religious life of the foreign settlement. In 1880, a school called Seishin Jo Gakko 聖心女学校, Sacred Heart Girls School was opened in Minamiyamate. The foremost Catholic school for boys in the Nagasaki foreign settlement was Kaisei Gakko 海星学校 and it was founded in 1892.

\section{E. Mitsubishi Nagasaki Shipyard}

Nagasaki was the first place in Japan where Western technology was introduced and industry was developed, including Mitsubishi Nagasaki Shipyards, where battleships were produced. Thomas Blake Glover established his residence over Minamiyamate and it is called Gurabatei グラバー亭, which is the oldest Western-style building in Japan. He made a big fortune by selling arms and warships to Satsuma and Choshu, which were rebellious factions against the Edo government. Also, the Scottish merchant began to develop Japan's first coal mine at Hashima Island, Takashimaya and brought the first dry dock to Japan early in the $19^{\text {th }}$ century.

\section{I-5. People}

A. Thomas Blake Glover (1838-1911)

As previously mentioned, Thomas Blake Glover was a key person in the industrialization of Japan. He founded his own firm, Guraba-Shokai, Glover and Co, starting his business of importing silk and tea. 
He brought a small steam locomotive, the "Iron Duke," on a short track in the Oura district. In 1876 Thomas Glover acted as the chairman of the Municipal Council, which played an important role in the early years of the foreign settlement.

\section{B. Philipp Franz von Siebold (1796-1866)}

Philipp Franz von Siebold was a German doctor and naturalist. He was one of the three Dejima scholars. He opened Narutaki School 鳴滝塾 in the suburb of Nagasaki and taught Japanese learners Dutch medical science there. Because he tried to take a detailed map of Japan with him on his return home, the Japanese government captured and expelled him in 1829. He did not return to Japan until 1859.

\section{Takano Choei 高野長英 (1804-1850)}

Takano Choei was a prominent scholar of Rangaku (Dutch studies). He studied under Siebold in the Dutch factory. The Morrison, an American merchant ship with Japanese drifters on board, came under fire by the Edo government in 1837 due to the Edict to Repel Foreign Vessels 異国船打ち払い令 (1825). Takano Choei heard about this incident and severely criticized the government's response to it, and he was sentenced to prison.

\section{Hakodate 箱館/函館}

\section{II-1. General}

Hokkaido, in the northern part of Japan, is generally cold all over the island, but Hakodate, which is on the Oshima peninsula, in the south-west of Hokkaido, is the exception. Hakodate has a mild climate throughout the year due to the Tsushima current and has less snow in winter. About 60 years before America came to Japan with Commodore Perry's arrival at Uraga, Yokohama in 1853, Russia had already knocked on Japan's door. At that time Siberia was an important trading area and Russia wanted Japan to supply foods to Siberia through trade. In 1792 Adam K. Laxman (1766-1806?), a Russian merchant, came to Nemuro, the most eastern part of Hokkaido and stayed there for eight months. He asked for trade rights with Japan but was refused, being told to go to Nagasaki for that kind of international business - in fact, he did not go to Nagasaki (Sato, 2018). As I mentioned in the section of Nagasaki, in 1804 Nikolai Rezanov (1764-1807) went there with a request of beginning trade with Japan but the shogunate government still did not accept it. Russia felt it necessary to use military force to push through its request, and the shogunate government opened the Matsumae magistrate in 1807 to prevent the country from feeling Russia's pressure. Furthermore the government took a more aggressive attitude toward refusing approach of foreign vessels to Japan by issuing the Edict to Repel Foreign Vessels. Local Japanese people were afraid of such an approach by foreign vessels to Hakodate. As fear had increased, more people emphasized the importance of the coastal defense. Hayashi Shihei 林子平 (1738-1793) was one of them. He wrote a book entitled Kaikoku Heidan 海国兵団, which emphasized the necessity of the coastal defense.

Toward the end of the $18^{\text {th }}$ century Japan's contact with Russia increased and Russia's interest in trade with Ezo-chi (Hokkaido) grew. In 1855 the Edo government decided to set up the Hakodate magistrate 箱館奉行 for defense and most of Ezo-chi was put under the direct control of the Hakodate magistrate. Incidentally Mamiya Rinzo (1780-1844) 間宮林蔵, an explorer, was employed by the Tokugawa shogunate to measure Ezo-chi and discovered that Sakhalin (Karafuto) was an island with a channel between Sakhalin and Russia.

The ShimodaTreaty was signed in 1857, providing America with trade settlements in Shimoda and Hakodate. (Shimoda is at the tip of the Izu Peninsula, south-west of Yokohama.) Then, based on the Treaty of Amity and Commerce Between the United States and the Empire of Japan concluded in 1859, Hakodate port as well as the Nagasaki and Kanagawa ports opened.

It should be noted that Hakodate already had contact with foreign countries before the openings of the Yokohama and Kobe ports. In other words, Perry's visit to Yokohama did not mark the first opening of Japan toward foreign countries as commonly understood. The histories of Nagasaki and Hakodate evidently tell that Japan had already been aware of foreign countries' interests, and thus, I argue that foreign settlements of Nagasaki and Hakodate, earlier than Yokohama and Kobe, brought in Western culture to Japan - that is, the beginning of the modernization of Japan.

\section{II-2. The Site of the Hakodate Foreign Settlement 箱館居留地}

Unlike the defined boundaries of the Yokohama, Kobe, and Nagasaki foreign settlements, the Hakodate foreign settlement was scattered throughout Hakodate. The main site of the Hakodate foreign settlement was the Omachi 大町 foreign settlement constructed in 1860, whose area was $1,730.381$ tsubo $\left(5,720 \mathrm{~m}^{2}\right)$ in 1878 . But the Hakodate magistrate thought that the Omachi foreign settlement alone was not large enough. Because of foreigners' strong request the Jizo 地蔵 foreign settlement was added, which had as much as 20,773 tsubo $\left(66,115 \mathrm{~m}^{2}\right)$. Unexpectedly, however, few foreigners were interested in the Jizo area and it remained barren. 
Beside the Omachi and the Jizo, some other foreign settlements were constructed. The Russian, Britain, and American consulates used to be in that area. Thus, the grand total of the 30 foreign settlements in Hakodate was 26,869.304 tsubo $\left(88,823 \mathrm{~m}^{2}\right)$.

Living dispersed outside of the foreign settlements, foreigners lived together with Japanese local people in a mixed area called zakkyochi 杂隹居地. The zakkyochi in Hakodate was 25, 165 tsubo $\left(83,190 \mathrm{~m}^{2}\right)$. The large mixed area was a feature of Hakodate, and in this sense Hakodate was different from the other foreign settlements: Yokohama, Kobe, and Nagasaki.

\section{II-3. The Population of the Hakodate Foreign Settlement}

Before a big fire broke out and devastated the area in 1878, the population of the Hakodate foreign settlement was 72 in total: 20 British, 6 French, 4 Russians, 3 Americans, 2 Danes, 2 Germans, and 35 Chinese. (Shimizu, 2013).

\section{II-4. The Characteristics of Hakodate}

\section{A. No Governance in the Hakodate Foreign Settlements}

The Yokohama, Kobe, and Nagasaki foreign settlements had a clear boundary between foreign areas and Japanese areas, and their foreign settlements existed not in dispersion but in concentration - the Edo government designated the areas of the foreign settlements and all foreigners were forced to live there. In the Hakodate foreign settlements, there was not as much controlled area. The Omachi area was the biggest in terms of foreign population living in concentration, but generally there were not many foreigners living in Hakodate. The Municipal Councils 居留地参事 会 were formed in Yokohama and Kobe (Watanabe, 2018,5). They were active with their own government, building roads, sewage, etc.; however, in the Hakodate foreign settlements, because there was not much population, there was no governance. Rutherford Alcock (1809-1897), the British ambassador to Japan, gave an interesting remark that merchants in the foreign settlements were "European trash"-- there were many merchants who were not educated, and also there was much prejudice against those types of people. In fact, among merchants in the foreign settlements there were two types of merchants, those with stores and those without, and that constituted a social gap or differences in their education and manners.

\section{B. The Hakodate Magistrate 箱館奉行}

In the latter $18^{\text {th }}$ century foreign vessels approached Japan and began to awaken or threaten the country, which had been sleeping in its long isolation. Under this international change Japan needed to protect itself from foreign countries, particularly Hakodate from Russia. The Ezo government was constructed in 1802 and the name of the Matsumae magistrate was changed in 1803 to the Hakodate magistrate. The new magistrate's office was constructed at the current Motomachi Park, where a nice view of the Hakodate port could be commanded. The Hakodate magistrate had been closed for some time until foreign vessels began to make another appearance near Japan. In 1853 Perry came to Uraga and in the next year the Convention of Peace and Amity between Japan and the USA 日米和親条約 was concluded. As a result, the ports of Shimoda and Hakodate opened. Since Japan urgently needed answers regarding the foreign incident, the Hakodate magistrate was revived by the Edo government and the Matsumae clan came to be under its direct control. Briefly the roles of the Hakodate magistrate included negotiation with foreign countries, protection of the Ezo coastline, and governance of Ezo-chi, placing Hakodate as the center of Ezo-chi. Consulate of foreign countries were placed in Hakodate and the magistrate of Hakodate played an important role in contact with foreign countries.

\section{Relations with Foreign Countries}

\section{Russia}

Four months before Perry's visit to Hakodate, Yevfimiy Putjatin (1803-1883) came to Hakodate and successfully signed the Treaty of Shimoda in 1855. The Japanese side favored Putjatin's negotiation attitude of respecting Japan's situation without threatening the country by force. In 1858 the first Russian Consulate was established in Hakodate, which has had a close relation with Russia ever since. In 1860 the Russian Orthodox Church was established and in the next year Nikolay Kassatkin (1836-1912) arrived in Hakodate to serve at the Consulate as a priest. He spread Orthodox Christianity among the local people. The relations between Japan and Russia were deepened in daily lives by cultural exchanges between the countries. For example, Nikolay contributed to making a Japanese-Russian dictionary. In response to such a positive attitude from Russia, the Japanese side sent some Japanese people to Russia to learn the art of navigation.

\section{China}

In comparison with Nagasaki, Hakodate did not have a close connection with China and in fact not many Chinese lived there. Thus, there was not much Chinese architecture in Hakodate except Chuka Kaikan, 中華会館, the Chinese Hall. 
Chinese merchants came to Hakodate, and constructed the building in 1910, where a Chinese warrior hero Guan Yu 関羽 was enshrined.

\section{The Ainu}

The Ainu, the indigenous people of Hokkaido, used to live in Hokkaido, the northern part of the Honshu island, Sakhalin, and the Kuril Islands. In 1871, when the Family Registration started, the Japanese government assimilated the Ainu to the Japanese and the Ainu became a part of the Japanese. The Ainu numbered 18,000 at the time the Hakodate port was opened, but the Japanese government ignored the Ainu's ethnicity and announced that there was no Ainu. The Ainu language was an "isolated language", a language, which proved to have no linguistic connection with other languages. In 1874 the education of the Ainu people began, and a British minister, Walter Dening (1846-1913), who edited the book of the Ainu language, was one of the activists. The Ainu language has been dying and is an "endangered language" and a statistic from 2007 states there were only 10 people left who spoke the Ainu language.

\section{E. The Northern Sea Fishery in the Pacific 北洋漁業}

The Northern Sea Fishery in the Pacific is defined as a fishery, located in the northern sea above the 45-degree latitude of the Pacific Ocean, the Bering Sea, and the Sea of Okhotsk. They caught salmon, trout, cod, herring, crab, etc. in those seas. Hakodate was one of the big fishing ports in Hokkaido and some other ports included Kushiro and Nemuro. Hakodate experienced ups and downs in economy of the Northern Sea Fishery. After the Meiji Restoration in 1868, as Hokkaido became more developed, many Japanese fishing boats went deep into the sea and made a big fortune by catching fish in the far seas. After the Russo-Japanese War ended in 1894 and the Russo-Japanese Treaty was concluded in 1907, the Northern-sea fishery was at its peak and Hakodate was the heart of the Northern Sea Fishery. The population of Hakodate was 100,000 in 1914 and went up to 217,000 in 1933. Because of the 200 kairi (about 370 $\mathrm{km}$ ) fishing zone law regulated in 1977 the Japanese fishery was restricted to fish in the Northern Sea. This brought great damage to the Hakodate ports and other fishing ports. Since then Hakodate has experienced a drastic loss of population and their fishing industry has been on the decline.

\section{II-5. People}

\section{A. Takadaya Kahei 高田屋嘉兵衛 (1769-1827)}

Takadaya Kahei was a merchant at Hakodate in the latter part of the Edo era. He was engaged in trade at Hakodate and made a big fortune. He was recognized for opening the northern Etorofu sea route to the Kuril island fisheries. He also greatly contributed to the Northern Sea Fishery and the improvement work of the Hakodate port.

\section{B. William Smith Clark (1826-1886)}

William Clark was the founder of the Hokkaido University (previously, the Sapporo Agricultural School). Clark was invited as a government employee to help to develop colonial troops, Tondenhei 屯田兵, whose responsibilities were to guard and develop new lands. Clark stimulated the development of a Christian movement in Japan. He left the famous words, "Boys, be ambitious."

C. Niijima Jo 新島裹 (1843-1890)

Niijima Jo was a Japanese missionary and an educator as well. In 1864 he escaped from the country illegally aboard a US ship off the coast of the Omachi foreign settlement and reached Boston. He graduated from Amherst College and became a missionary at a church in Boston. Being a sincere Christian, he returned to Japan and founded Doshisha University in Kyoto in 1912.

\section{Summary}

Both Nagasaki and Hakodate were remote from Edo but they had early contacts with foreign countries. They were bigger and thriving more than Yokohama and Kobe. At that time people might have paid more attention to the geographic center of the North (Hakodate) and the center of the South (Nagasaki) rather than the centers of Mid-Japan (Yokohama and Kobe). The area of the Nagasaki foreign settlement was quite large, 338,376 $\mathrm{m}^{2}$ (Yokohama: 1,161,175 $\mathrm{m}^{2}$; Kobe 257,850 $\mathrm{m}^{2}$ ). The total population of Nagasaki was 862 in 1876 (Yokohama: 4,494 in 1888; Kobe: 1,110 in 1888). Nagasaki is influenced by China. It has had close relations with China for a long time and we can see much influence of China on Nagasaki. For example, we can easily find Chinese-like temples, such as Kofukuj and Sofukuji. The Shinchi and Hirobaba districts are now Chinese communities. They have the Dragon Dance festival and Chanpon, a unique dish mixed with Chinese dishes. Chinese people have had active interactions with Japanese beyond Japan's borders and have established good relations with Japanese.

Christianity colors Nagasaki, too. There are as many as 971 Christian churches in Nagasaki and Oura Cathedral is a symbol of Christianity. Missionaries have left many Christian schools at Minamiyamate. Nagasaki was a multinational community - it had early contact with China, Portugal, and the Netherlands and presents multicultural heritage. 
On the other hand, Hakodate is completely different from Nagasaki. The area of the Hakodate foreign settlementwas not large $\left(88,823 \mathrm{~m}^{2}\right)$ and it included Omachi and Jizo. "Foreigners, however, did not like the shallow waters or being so far from the center of the city at that time." (Suzuki, 2015, 22) The total population was only over 50 in 1868. Hokkaido is near Russia and such geographical nearness enabled Hakodate to have early contact with Russians in the $19^{\text {th }}$ century, and that was before Perry came to Yokohama in 1853 and 1854. Hakodate's foreign settlements, however, were scattered and there were not many foreigners living in concentration, and thus there was no governance by foreigners.

Hakodate has its uniqueness, such as the indigenous Ainu culture. Also, Russian influence on Hakodate can be found in the Russian Orthodox Church. The Northern-sea fishery enabled Hakodate to develop the leading fishing industry in the world in early $20^{\text {th }}$ century.

\section{Comparative Study of Nagasaki and Hakodate, focusing on their Foreign Settlements}

\begin{tabular}{|l|l|l|}
\hline & The Nagasaki Foreign Settlement & The Hakodate Foreign Settlement \\
\hline Period & $1859-1911$ & $1859-1911$ \\
\hline Sites & $\begin{array}{l}\text { Higashi Yamate, Minami Yamate, Oura, Sagarimatsu, } \\
\text { Umegasaki, and Dejima. The total of the six areas is } \\
102,350 \text { tsubo }\left(338,376 \mathrm{~m}^{2}\right) . \\
\text { Chinese foreign settlements are 6,900 tsubo }\left(22,809 \mathrm{~m}^{2}\right) .\end{array}$ & $\begin{array}{l}\text { Omachi, Jizo, etc. } \\
\text { Total of 30 foreign settlements is } 26,869 \\
\text { tsubo }\left(88,823 \mathrm{~m}^{2}\right) . \\
\text { Barren and scattered areas with low } \\
\text { population }\end{array}$ \\
\hline Designers & Harry Smith Parks (1828-1885). & Unidentified. \\
\hline \multirow{2}{*}{$\begin{array}{l}\text { Relations } \\
\text { with foreign } \\
\text { countries }\end{array}$} & $\begin{array}{l}\text { was } 862 \text { in 1876. The population breakdown by country } \\
\text { was China (616), Britain (131), America (39), France } \\
\text { (21), Germany (15), etc. }\end{array}$ & $\begin{array}{l}\text { A little over 50 in 1868, which was the } \\
\text { peak of the population in the foreign } \\
\text { settlement in Hakodate. Not many } \\
\text { foreigners; much fewer Chinese. No } \\
\text { governance by foreigners. }\end{array}$ \\
\hline Heritages & $\begin{array}{l}\text { Strong influence of Christianity and China. Christian } \\
\text { churches in Nagasaki occupied 13.7\% of all churches in } \\
\text { Japan. } \\
\text { Chinese architecture. } \\
\text { Western technology was first introduced. (e.g. Mitsubishi } \\
\text { Nagasaki Shipyard) }\end{array}$ & $\begin{array}{l}\text { The relationship between Japan and } \\
\text { Russia was deepened in daily life. There } \\
\text { was not much contact with China. }\end{array}$ \\
$\begin{array}{l}\text { The unique influence by Russia like the } \\
\text { Russian Orthodox Church. } \\
\text { The Ainu heritage. } \\
\text { The Northern sea fishery enabled } \\
\text { Hakodate and some other cities to develop } \\
\text { a leading fishing industry. }\end{array}$ \\
\hline
\end{tabular}

\section{References}

Brian Burke-Gaffney. (2006). Nagasaki: A History in Picture Postcards, Nagasaki Bunkensha.

Kanagawa Prefectural Museum of Cultural History. (2019). Kitakarano Kaikoku, Kanagawa Prefectural Museum of Cultural History.

Sato, Makoto. (2018). Nihonshi Kenkyu. Yamakawa Shuppansha.

Shimizu, Kensaku. (2016). Gaikokujin Kyoryuchi Gaido Map, Study Group of Foreign Settlements in Hakodate.

Suzuki, Chizuko (translation leader). (2015). Hakodate Through 150 Images Japan's Surprising Pioneer, Study Group of Foreign Settlements in Hakodate.

Hori, Hiroaki. (2013). Tabisuru Nagasakigaku 7, Nagasaki Bunkensha.

Hori, Hiroaki. (2013). Tabisuru Nagasakigaku 8, Nagasaki Bunkensha.

Hori, Hiroaki. (2011). Tabisuru Nagasakigaku 9, Nagasaki Bunkensha.

Watanabe, Hideo. (2018). Foreign Settlements and Modernization: The Cases of Yokohama and Kobe. International Journal of Humanities and Social Science. Vol. 8, No. 4, April 2018. 


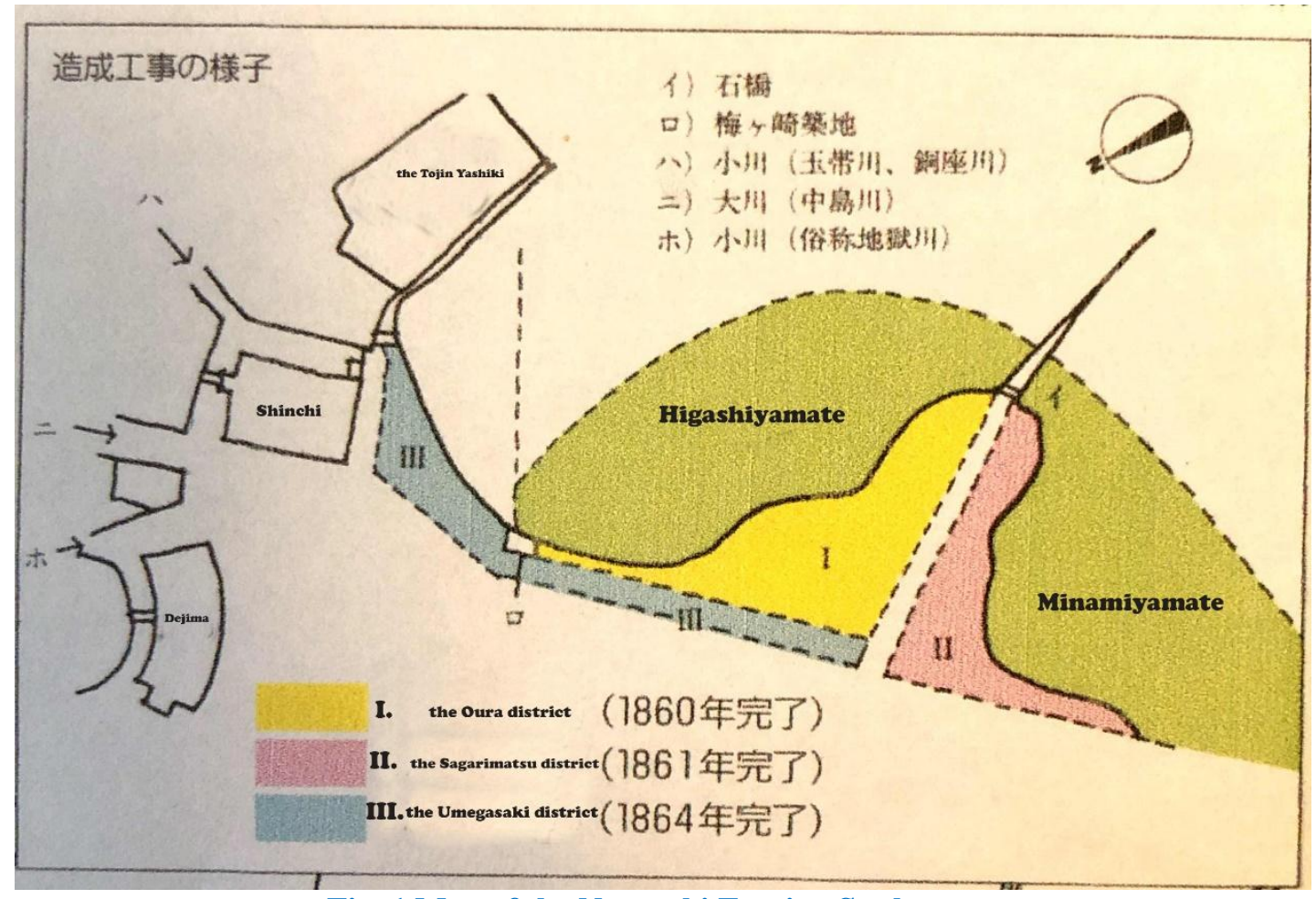

Fig. 1 Map of the Nagasaki Foreign Settlement

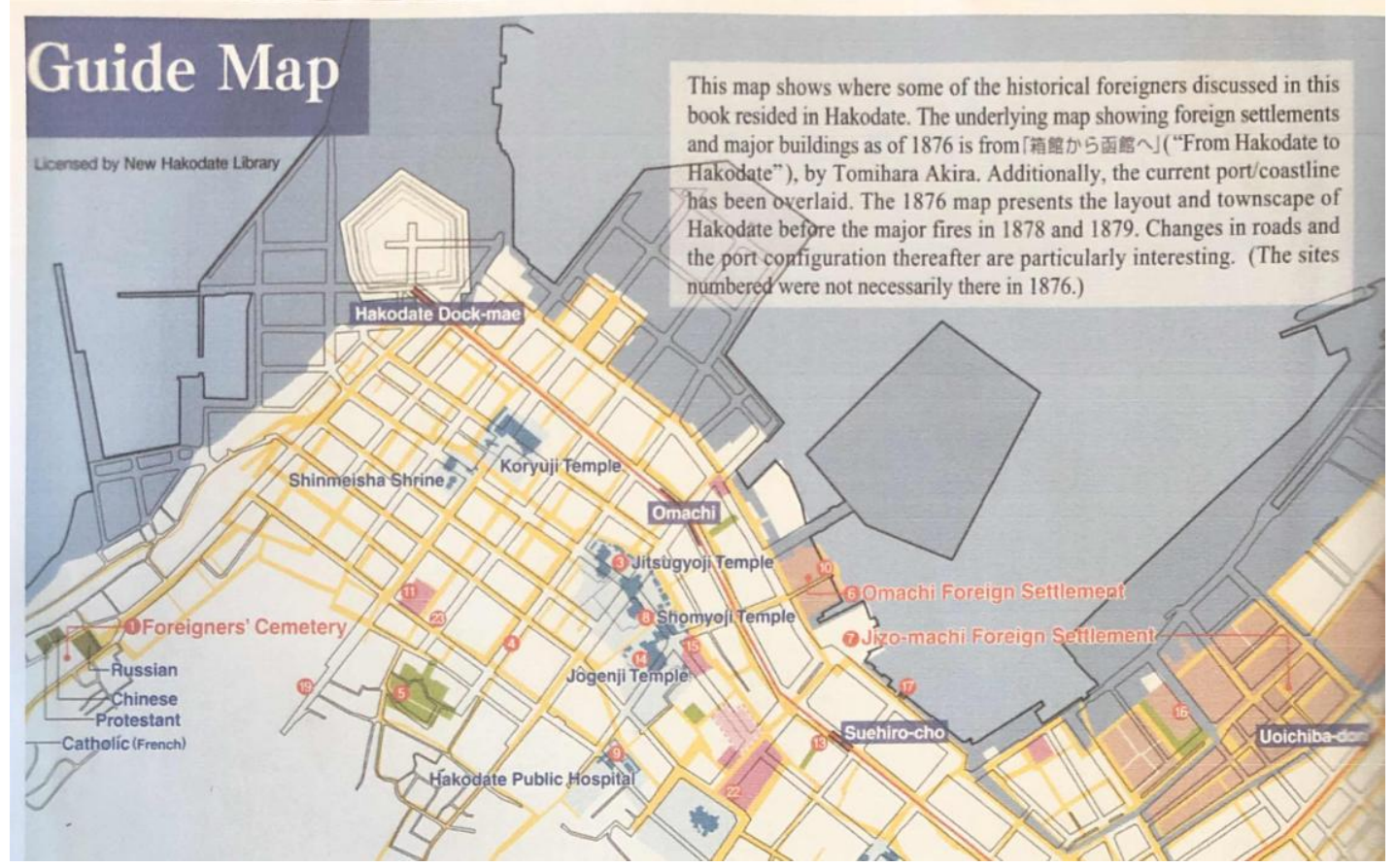

Fig. 2 Map of the Hakodate Foreign Settlement 